\title{
Instructional Design Using the Dick and Carey Systems Approach ${ }^{1}$
}

\author{
Tyler D'Angelo, J. C. Bunch, and Andrew Thoron ${ }^{2}$
}

\section{Introduction}

Instructional design is a system of procedures used for developing instruction and training curricula in a consistent and reliable method (Reiser, Reiser, \& Dempsey, 2011). While the system of procedures varies, the structure of the design should be both engaging and effective for the learner. This publication applies the best practices of instructional design using the Dick and Carey systems approach. When designing instruction, it is imperative to promote good design for learning. High-quality instructional design that promotes learning possesses the following characteristics (Reiser et al., 2011):

- Performance goals that are genuine and explicit;

- Focused on ideas, questions, issues, concepts, and problems;

- Real-world application;

- Responsive feedback system with opportunities to learn through trial and error;

- Individualized approaches so learners can process and develop interest;

- Vary methods, grouping, and tasks;

- Create a safe environment and encourage risks;

- Instructor assumes the role as a mentor;
- Sharing the overall objective of the course and assignments.

\section{What is the Dick and Carey systems approach?}

The systems approach by Dick and Carey helps instructional designers develop curricula through a series of nine steps which work together toward a defined instructional goal (Dick, Carey, \& Carey, 2005). The Dick and Carey systems approach considers components such as the instructor, learners, materials, instructional activities, delivery system, and the learning and performance environment. Unlike traditional models, the Dick and Carey systems approach is portrayed as a curvilinear flow portrayed with one-way arrows. The curvilinear design portrays an easier way instructional design is practiced and developed (Branch, 1996).

1. This document is AEC632, one of a series of the Department of Agricultural Education and Communication, UF/IFAS Extension. Original publication date March 2018. Visit the EDIS website at http://edis.ifas.ufl.edu.

2. Tyler D'Angelo, graduate assistant; J. C. Bunch, assistant professor; and Andrew Thoron, assistant professor, Department of Agricultural Education and Communication; UF/IFAS Extension, Gainesville, FL 32611.

The Institute of Food and Agricultural Sciences (IFAS) is an Equal Opportunity Institution authorized to provide research, educational information and other services only to individuals and institutions that function with non-discrimination with respect to race, creed, color, religion, age, disability, sex, sexual orientation, marital status, national origin, political opinions or affiliations. For more information on obtaining other UF/IFAS Extension publications, contact your county's UF/IFAS Extension office. 


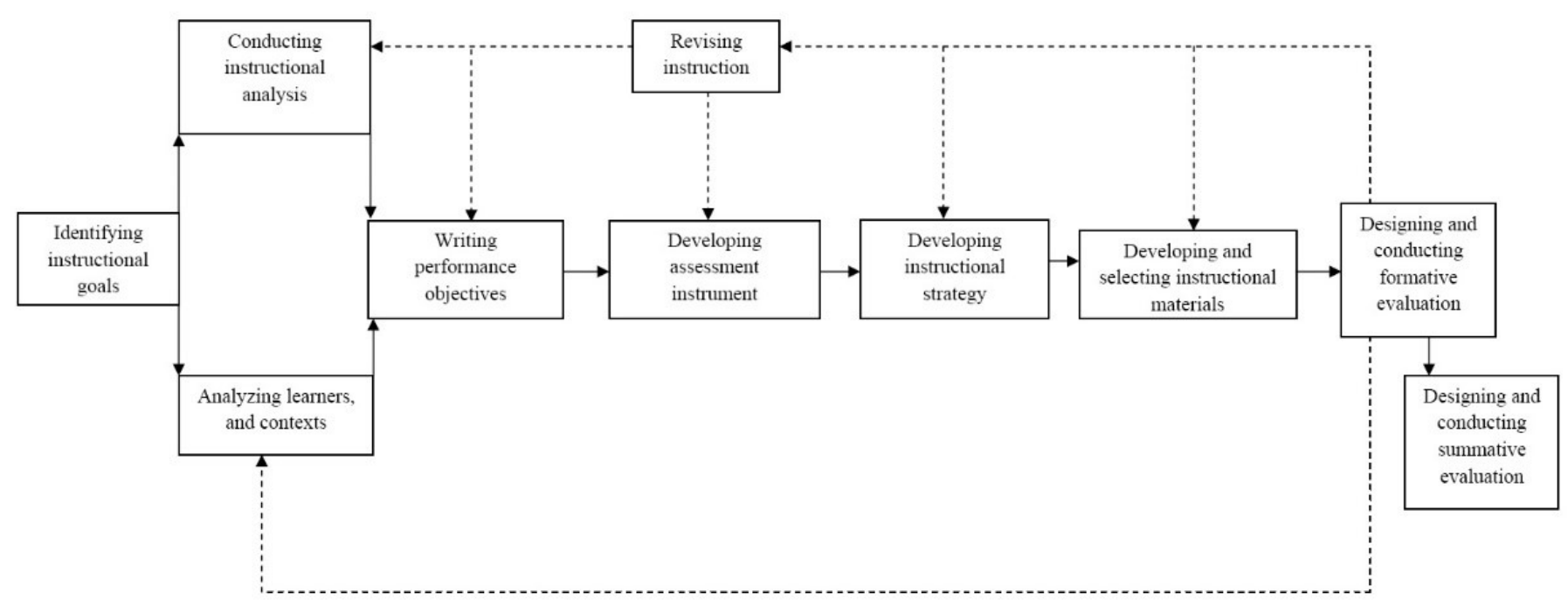

Figure 1. The Dick and Carey Systems Approach Model.

Credits: Dick et al., 2005

\section{Stage 1. Identifying Instructional Goals}

A critical part of the instructional design process is the identification of the instructional goal(s) (Dick et al., 2005). When developing instructional goals, it is best to consult with a subject matter expert. A subject matter expert is the expert in the field for which the curriculum is being designed. A subject matter expert and creator(s) of the curriculum should use a needs assessment to determine the needs of the learners. A needs assessment can be conducted by using an equation from Borich (1979), and can be represented by:

\section{Desired status - Actual status $=$ Need}

The desired status is the intended competency level of the learner at the conclusion of the course. The actual status is where the learners are before the course, and the need is the gap between where the learners are presently and where they are to be at the end of instruction. Once a need has been established, goals can then be created. A completed goal statement should include (a) the learners, (b) what the learners will be able to do in the performance context, (c) the performance context in which the skills will be applied, and (d) the tools that will be available to the learners in the performance context (Dick et al., 2005). Revisions for instructional goals will need to be made until each component is included in the instructional goals.

\section{Stage 2. Conducting Instructional Analysis}

Once instructional goals are established, an instructional analysis can be developed. An instructional analysis is a set of procedures that help identify the skills and knowledge that should be included in instruction. It is important to identify which domain each instructional goal is linked to. Bloom defines the following learning domains of learning outcomes (Bloom, Engelhart, Furst, Hill, \& Krathwohl, 1956):

- Psychomotor Domain

- Affective (Attitude) Domain

- Cognitive Domain

- Knowledge

- Comprehension

- Application

- Analysis

- Synthesis

- Evaluation

\section{Stage 3. Analyzing Learners and Context}

When determining the learners and the context in which the learning will take place, it is important to refer to the target population. The target population is the group of learners that you are trying to reach in instruction (Dick et al., 2005). When considering the target population, it is important to go beyond the context of the learner. When designing curriculum, the designer should consider the following about the target population:

- Skills prior to instruction

- Prior knowledge of the topic area

- Attitudes toward content and potential delivery

- Academic motivation

- Education and ability levels 
- Learning preferences

- Group characteristics

\section{Stage 4. Writing Performance Objectives}

A performance objective is a description of what the learners will be able to do by the end of the unit of instruction (Dick et al., 2005). A performance objective should be written into three parts: (a) conditions, (b) behavior, and (c) criteria.

- Conditions $(\mathrm{CN})$ : a description of the skill identified with the tools and resources needed to achieve the skill (Dick et al., 2005).

- Behavior (B): a description of the skill including actions, content, or concepts.

- Criteria (CR): a description of acceptable performance of the skill.

Examples include the following:

- Given a welding torch $(\mathrm{CN})$, turn on the welding torch (B). Determine the welding settings, ground the welder, and adjust the wire voltage properly without assistance from the instructor (CR).

- During a meeting held on campus $(\mathrm{CN})$, successfully demonstrate three different motions on an agricultural issue as the main motion (B). Proper use of motions based on Robert's Rules of Order will be used to judge achievement of this goal (CR).

- Given a blank diagram of the primal cuts of beef $(\mathrm{CN})$, identify the primal cuts of beef (B). Learner should identify at least $80 \%$ of the primal cuts correctly (CR).

For more information on writing performance objectives, visit EDIS AEC583 (http://edis.ifas.ufl.edu/wc245).

\section{Stage 5. Developing Assessment Instruments}

Once performance objectives have been determined and written, it is important to consider the question, "What type of assessment(s) should be used to assess the learners' performance?" Figure 2 indicates the various ways behaviors can be assessed, and indicates which types of assessments are appropriate for individual behavioral objectives. It is important to consider the environment in which the assessments will take place, the response time needed by the learners, and the probability of guessing the correct answer.

\begin{tabular}{|c|c|c|c|c|c|c|c|}
\hline \multirow[b]{2}{*}{ Type of Behavior Stated in Objective } & \multicolumn{7}{|c|}{ Types of Test Items } \\
\hline & 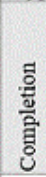 & $\begin{array}{l}\frac{4}{3} \\
\frac{5}{4} \\
\frac{5}{n}\end{array}$ & 竞 & 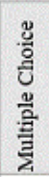 & $\begin{array}{l}\text { 总 } \\
\text { 总 }\end{array}$ & 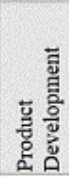 & 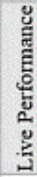 \\
\hline State/Name & $\mathrm{x}$ & $\mathrm{X}$ & & & & & \\
\hline Define & $\mathrm{X}$ & $\mathrm{x}$ & $\mathrm{X}$ & $\mathrm{x}$ & & & \\
\hline Identify & $\mathrm{X}$ & $\mathrm{X}$ & $\mathrm{x}$ & $\mathrm{x}$ & & & \\
\hline Discriminate & & $\mathrm{x}$ & $\mathrm{x}$ & $\mathrm{x}$ & & & \\
\hline Select & & $\mathrm{x}$ & $\mathrm{X}$ & $\mathrm{X}$ & & & \\
\hline Locate & & $\mathrm{x}$ & $\mathrm{X}$ & $\mathrm{x}$ & & & \\
\hline Evaluate/Judge & & $\mathrm{X}$ & $\mathrm{X}$ & $\mathrm{X}$ & & & \\
\hline Solve & & $\mathrm{x}$ & $\mathrm{X}$ & $\mathrm{x}$ & $\mathrm{X}$ & $\mathrm{X}$ & $\mathrm{X}$ \\
\hline Discuss & & & & & $\mathrm{X}$ & & $\mathrm{X}$ \\
\hline Develop & & & & & $\mathrm{x}$ & $\mathrm{X}$ & $\mathrm{X}$ \\
\hline Construct & & & & & $\mathrm{X}$ & $\mathrm{X}$ & $\mathrm{X}$ \\
\hline Generate & & & & & $\mathrm{x}$ & $\mathrm{x}$ & $\mathrm{x}$ \\
\hline Operate/Perform & & & & & & & $\mathrm{X}$ \\
\hline Choose (attitude) & & & & & & & $\mathrm{X}$ \\
\hline
\end{tabular}

Figure 2. The type of behavior and related item types. Credits: Dick et al., 2005

\section{Stage 6. Developing an Instructional Strategy}

An instructional strategy is a variety of teaching and learning strategies, which may include group discussions, independent reading, lectures, computer simulations, worksheets, lab work, and much more (Dick et al., 2005). This is generally known as instruction. When considering the instructional strategies for a unit of instructions, there are a few things to consider, such as the goal, the learner motivation and characteristics, the learning objectives, assessment requirements, and the performance context.

\section{Stage 7. Developing and Selecting Instructional Materials}

The instructional materials contain the content. This can be either written information or facilitated by an instructor that the student will use to achieve the objectives (Dick et al., 2005). This may include any materials that are being incorporated into a lesson. Examples of this may include student workbooks, activity guides, problem scenarios, resource lists, textbooks, or computer simulations. When selecting and developing instructional materials, it is imperative to align the materials to both the objectives in Stage 4 and the assessment instruments in Stage 5.

\section{Stage 8. Designing and Conducting Formative Evaluation}

Formative evaluation is the collection of data and information during instruction that can be used to look at the effectiveness of instruction (Dick et al., 2005). Formative evaluation should be conducted within the instruction, and happening as instruction is taking place. However, formative evaluations may not always take place in non-formal 
instruction. Formative evaluations can be completed in many ways. Examples may include:

- Questioning content

- Observations of learners

- Record analysis

- Interviews

- Self-assessments

- Short quizzes

- Discussion

\section{Stage 9. Designing and Conducting Summative Evaluation}

Summative evaluation is a collection of data that looks at the effectiveness of instruction as a whole (Dick et. al., 2005). Summative evaluation measures an entire unit of instruction and multiple performance objectives. When developing the summative evaluation, it is important that the objectives match the summative evaluation. Summative evaluations differ from formative evaluations. The main difference is the purpose for conducting an evaluation. Formative evaluations identify improvements needed during instruction, whereas summative evaluations identify strengths and improvements after instruction.

\section{Example Scenario (Formal Education)}

Ms. Byers, a first year agriscience educator, is having a hard time developing a unit of instruction on basic electricity principles. Ms. Byers thought about how she was going to compile all of the information she had into a lesson. At first, she consulted with Mr. Rigby, who just so happened to have been an electrician before working as a teacher at the school. Mr. Rigby gave her some advice on he would teach the course. Ms. Byers used that information to develop the instructional goals for the unit. She knew that most of her students would most likely not have any prior information on electricity. After she assessed where her students were, she started to think about what learning domains she would be utilizing for instruction. She agreed that much of the class would follow Blooms' knowledge, comprehension, and application domains in the classroom. She would also like to utilize her mechanics shop for psychomotor learningwhere students will take what they have learned in class and wire given models. She then started to build performance objectives for her unit. She referred back to her state standards to develop a list of performance objectives. One of the objectives that she found read, "Given a diagram $(\mathrm{CN})$, identify the principles of AC and DC circuitry (B) at the instructor's satisfaction (CR)". Ms. Byers plans to do a short quiz with a multiple-choice layout to test her students. Ms. Byers hopes to accomplish this objective through lecture and additional reading that aligns well with the learning objective. Ms. Byers also plans to have students refer to the Intro to Agricultural Operations textbook if need be. As part of the summative assessment for her unit of instruction, Ms. Byers hopes to use a psychomotor approach by assigning a wiring project as part of her summative assessment.

\section{Example Scenario (Non-Formal Education)}

Mr. Baker, an extension agent, has been asked to do a series of instruction on invasive insect species in the county. Since Mr. Baker does not have a background in entomology, he consults with Ms. Carter, who is an Extension agent in the county over. Ms. Carter has an extended background in invasive insects through her time as a Masters student. With the help of Ms. Carter, Mr. Baker devises a set of instructional goals for the program he is developing. He knows that many of the learners who will be taking his course are farmers in the county who want to know how to identify invasive insect species, as well as new ways to use Integrated Pest Management (IPM) practices on their farm operation. Ms. Carter and Mr. Baker both agree that much of the curriculum will be taught around knowledge, comprehension, and then application of the knowledge on their own farm. Mr. Baker wants to be sure that the knowledge he is providing can actually be applicable, otherwise, he knows that many of the farmers will not want to come to his course. Ms. Carter helps him develop a series of units and builds a set of performance objectives. One of the objectives that he develops reads, "Given a dichotomous key and information from presentation $(\mathrm{CN})$, construct an IPM program (B) that successfully limits invasive pests on the farm (CR)". Mr. Baker, inferring what he knows about adult learners, feels that hands-on application to real-world scenarios on the farm will be the best way to assess the success of his learners. To instruct his learners, Mr. Baker hopes to utilize lecture, group discussion, and a field trip to a local farm that has had success with invasive insects. Mr. Baker is planning to utilize a book developed by Ms. Carter titled Invasive Plant Species in North Florida. He hopes to focus on questioning content and observation of the learners to gauge in formative assessments. Mr. Baker is planning on the successful use of IPM on the farm to be the summative assessment for the learners. 


\section{Conclusion}

By taking the time to plan a unit of instruction using the Dick and Carey systems approach model, instructors will be more effective on individualized learning. The nine components of the Dick and Carey model are meant to provide a cohesive and effective tool in developing an organized unit of instruction. The use of these components in instructional design can help learners acquire a systematic structure of learning and promote academic success.

\section{References}

Borich, G. (1979). Implications for developing teacher competencies from process-product research. Journal of Teacher Education, 30(1), 77-86.

Branch, R. (1996). Instructional design as a response to the complexities of instruction. In N. Venkataiah (Ed.), Educational technology (pp. 21-49). New Delhi: S. B. Nangia for APH Publishing Corporation.

Bloom, B. S., Engelhart, M. D., Furst, E. J., Hill, W. H., \& Krathwohl, D. R. (1956). Taxonomy of Educational Objectives, Handbook I: The Cognitive Domain. New York, New York: David McKay Co Inc.

Dick, W., Carey, L., \& Carey, J. O. (2005). The systematic design of instruction. Boston, Massachusetts: Pearson/Allyn and Bacon.

Reiser, R. A., Reiser, R. A., \& Dempsey, J. V. (2011). Trends and issues in instructional design and technology. Boston, Massachusetts: Pearson. 